\title{
QUALITATIVE RESEARCH ON LEGAL EDUCATION: STUDYING OUTSTANDING LAW TEACHERS
}

\author{
GERALD F. HESS*
}

This article advocates that law schools and law teachers should use high quality, rigorous, qualitative research to help them make thoughtful changes in response to current challenges facing legal education. Regardless of the type of study, qualitative research involves a five stage process: (1) study design and ethics; (2) sampling; (3) data collection; (4) data analysis; and (5) the research report.

This article illustrates each stage of the qualitative research process through a study of outstanding law teachers that was reported in the recent book, What the Best Law Teachers Do. This book is based on a study that was designed to identify the characteristics and practices of extraordinary law teachers who have significant, positive, long-term effects on their students.
Cet article préconise que les écoles et les professeurs de droit doivent utiliser une recherche qualitative, rigoureuse et de grande qualité pour les aider à apporter des changements judicieux en réponse aux défis actuels auxquels la formation en droit fait face. Peu importe le genre d'étude, la recherche qualitative comporte les cinq processus suivants, c'està-dire 1) un modèle d'étude et l'éthique; 2) l'échantillonnage; 3) la collecte de données; 4) l'analyse des données et 5) le rapport de la recherche.

Cet article illustre chaque étape du processus de la recherche qualitative au moyen de l'étude d'excellents professeurs de droit signalée dans le récent ouvrage intitulé en anglais, What the Best Law Teachers Do (Ce que les meilleurs professeurs de droit font). Ce livre est basé sur une étude conçue pour identifier les caractéristiques et les pratiques d'excellents professeurs de droit qui ont un effet important, positif et à long terme sur leurs étudiants.

\section{TABLE OF CONTENTS}

I. INTRODUCTION . . . . . . . . . . . . . . . . . . . . . . . . . . 925

II. NATURE AND TyPes OF QUALITATIVE RESEARCH . . . . . . . . . . . . 926

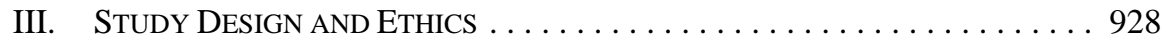

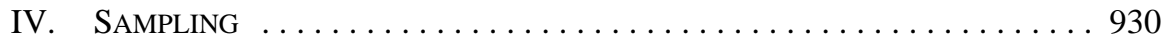

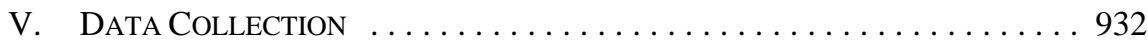

A. INTERVIEWS . . . . . . . . . . . . . . . . . . . . . . . 932

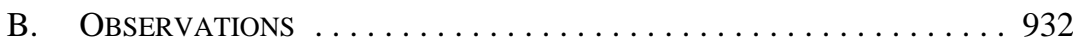

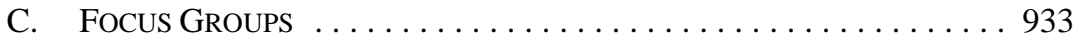

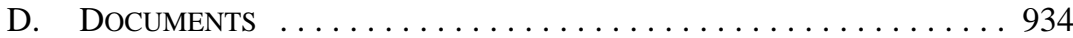

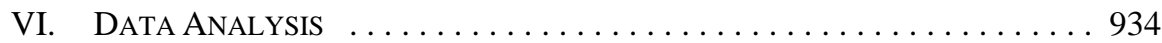

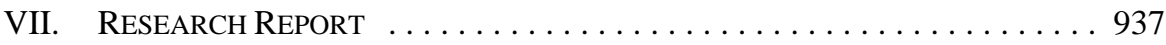

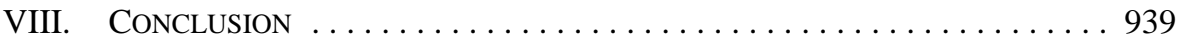

\section{INTRODUCTION}

In the second decade of the 21st century, legal education in Canada and the United States faces significant challenges. Many students graduate deeply in debt and struggle to find appropriate employment. Yet large segments of the population do not have access to affordable legal services. Law schools are under pressure to provide students with effective

Professor of Law, Gonzaga University, School of Law. Professor Hess is a co-author of a number of books on teaching and learning in law school, including the book examined in this article. The author thanks Gonzaga University for its support and Professors Sophie Sparrow and Eric Adams for their helpful comments. 
legal education at a reasonable cost. Law schools seek to distinguish themselves in a competitive legal education market. Law school curricula, teaching methods, and accreditation standards are evolving to keep pace with the rapid change in modern law practice.

Research on legal education can play an important role in the evolution of law schools. High quality research studies can help law schools make thoughtful decisions about appropriate curricula and direction. Likewise, results of rigorous research can guide law teachers as they develop their courses and teaching methods.

The focus of this article is qualitative research on legal education. This article identifies characteristics of rigorous qualitative research so that legal educators can assess the value of existing qualitative research. Further, this article provides a framework for conducting effective qualitative research in the future. Throughout the article, the characteristics of, and framework for, qualitative research are illustrated by a study of outstanding law teachers.

\section{NATURE AND TyPES OF QUALITATIVE RESEARCH}

Qualitative research studies people or phenomena as they occur in the real world. Qualitative researchers gather qualitative data — words and images — often through interviews and observations. Because human behaviours, including teaching and learning, are complex, they should be studied in-depth over an extended period of time. Employing the inductive mode of the scientific method, the goal of qualitative researchers is often exploration or discovery. Qualitative researchers develop explanations and theories based on what they have observed. The product of qualitative research is a narrative report, rich in detail. $^{1}$

Four types of qualitative research are common in educational research: phenomenology, ethnography, case study, and grounded theory. Although the four types have much in common, each has a different emphasis. ${ }^{2}$ The following paragraphs describe the characteristics of each type of qualitative research and offer examples from the legal education literature.

Phenomenology is the description of one or more individuals' experience of a phenomenon, such as teaching in law school. The purpose of phenomenological research is to understand the subjects' consciousness and experience regarding the phenomenon. Data is developed through in-depth interviews. During data analysis, researchers search for significant statements from the interviews and identify themes in the data. The phenomenological research report includes rich descriptions of the subjects' experiences and

Burke Johnson \& Larry Christensen, Educational Research: Quantitative, Qualitative, and Mixed Approaches, 4th ed (Thousand Oaks, Cal: SAGE Publications, 2012) at 366-67. In contrast, quantitative research seeks to study behaviour under controlled conditions, focusing on a single or a few factors while holding all other factors constant (ibid at 33-37). Quantitative researchers begin with a hypothesis that they seek to confirm. They often assign volunteers randomly to two groups and expose the groups to different conditions (such as different teaching methods). Quantitative researchers gather numerical data and use statistical analysis to identify relationships among variables. The focus of the final report is the statistical significance of the findings. Ibid at 382-83. 
presents the fundamental structure of the experience that emerges from the data. ${ }^{3}$ For example, Aïda Alaka studied how 10 students viewed the role of legal writing in law practice and how they experienced and reacted to critiques of their writing in a first-year legal writing course. ${ }^{4}$ Alaka's study illuminated how law students responded to or ignored different types of comments on their writing and the extent to which they underestimated the importance of effective writing in law practice. ${ }^{5}$ Based on those findings, Alaka made cogent recommendations to help law teachers alter their commenting practices to enhance student learning and to guide law schools in designing curricula to increase the writing skills of their graduates. $^{6}$

Ethnography is the discovery and description of the culture of a group of people, such as second career law students. Researchers gather data by observing the group in the field over an extended period of time and interviewing group members. Data analysis searches for cultural themes. The ethnographic research report includes detailed description of the group, the context in which the group operates including the physical and social settings, as well as the cultural themes that emerge from the data. ${ }^{7}$ For example, Mary Helen McNeal examined the culture of lawyering in Baltimore, Maryland and Missoula, Montana, and the effects of the lawyering culture on an externship director, supervising attorneys, and students in law school externship programs. ${ }^{8}$ McNeal's study found that local lawyering culture played a central role in the practice of law and that the local lawyering culture presented strategic and ethical issues to clinical law students and practitioners. ${ }^{9}$ McNeal offered suggestions to help clinical law teachers prepare students for transitions to new communities of law practice during their careers. ${ }^{10}$

Case study is a detailed account of one or more cases. An intrinsic case study focuses on in-depth understanding of a specific case, such as one law school's pro bono program. A collective case study examines several cases, such as several deans during their first year as law school leaders, allowing the researcher to more effectively generalize the results. Researchers gather data through multiple methods, including observation in the field, interviews, focus groups, questionnaires, and document reviews. The case study research report provides a vivid, detailed description of the case and its context, as well as implications from the case. ${ }^{11}$ For example, Joseph Rosenberg studied the design and delivery of a lawyering skills course blending online and face-to-face instruction. ${ }^{12}$ Rosenberg described the process of transforming a traditional class into a blended format, identified the key elements of a successful hybrid course, and illustrated the benefits and problems of teaching law in a hybrid format. ${ }^{13}$ Rosenberg's article provided guidance to law teachers in

Ibid at 383-88.

Aïda M Alaka, “Phenomenology of Error in Legal Writing” (2009) 28:1 Quinnipiac L Rev 1.

Ibid at $15-48$.

Ibid at 49-65.

Johnson \& Christensen, supra note 1 at 389-95.

Mary Helen McNeal, "Slow Down, People Breathing: Lawyering, Culture and Place” (2011) 18:1

Clinical L Rev 183.

Ibid at $188-220$.

Ibid at 220-41.

Johnson \& Christensen, supra note 1 at 395-99.

Joseph A Rosenberg, “Confronting Clichés in Online Instruction: Using a Hybrid Model to Teach Lawyering Skills” (2008) 12:1 SMU Science \& Technology Law Review 19.

Ibid at 28-81. 
adapting their courses to achieve better student learning through this promising course format.

Grounded theory is generated inductively from the data to describe and explain a phenomenon, such as how deans facilitate development of faculty members. Data is gathered primarily through open-ended interviews with 20 to 40 subjects. Researchers construct a grounded theory by identifying concepts, themes, and patterns in the data that show how the phenomenon operates in real life. The grounded theory research report describes the topic, the people studied, the methods of data collection, and the principles that emerged from the data. ${ }^{14}$ What the Best Law Teachers Do is an example of grounded theory qualitative research in legal education. ${ }^{15}$ The authors studied 26 outstanding law teachers in the US. Data gathering included open-ended interviews with the teachers, focus groups with their students, observations of the teachers in their classrooms, and review of student evaluations of the teachers' courses. ${ }^{16}$ The research resulted in a book describing the common characteristics and practices of law teachers whose students achieve exceptional learning.

Regardless of the type of study, qualitative research can be approached as a five-stage process: (1) study design and ethics; (2) sampling; (3) data collection; (4) data analysis; and (5) the research report. ${ }^{17}$ Each stage is discussed below and illustrated with the Best Law Teachers study.

\section{STUDY DESIGN AND ETHICS}

In designing a qualitative study, the researcher identifies a topic and research problem, specifies the purpose of the study, and articulates research questions. A literature review informs each of those design components. ${ }^{18}$

A research topic is the broad subject matter that the study will address. A research problem narrows the topic to an issue or controversy that the study will explore. ${ }^{19}$ The topic of the Best Law Teachers study is law school teaching. The research problem is the characteristics of "extraordinary law teachers, teachers who have a significant, positive, and long-term effect on their students." 20

In educational research generally, a purpose statement is the major objective of the study and research questions narrow the purpose into the specific questions that the study will

$14 \quad$ Johnson \& Christensen, supra note 1 at 399-405.

Michael Hunter Schwartz, Gerald F Hess \& Sophie M Sparrow, What the Best Law Teachers Do (Cambridge, Mass: Harvard University Press, 2013) [Best Law Teachers].

Ibid at 4-12.

This five-stage model is synthesized from two leading texts on educational research. Johnson and Christensen set out eight steps for a qualitative research study: (1) select a research topic; (2) determine research questions; (3) design the study; (4) collect data; (5) analyze data; (6) generate findings; (7) validate findings; and (8) write a research report (supra note 1 at 377-78). John Creswell sets out a sixstep research process: (1) identifying a research problem; (2) reviewing the literature; (3) specifying a purpose for research; (4) collecting data; (5) analyzing and interpreting the data; and (6) reporting and evaluating research (John W Creswell, Educational Research: Planning, Conducting, and Evaluating Quantitative and Qualitative Research, 4th ed (Boston: Pearson, 2012) at 7-11).

Creswell, ibid at 7-9.

Ibid at 60 .

Best Law Teachers, supra note 15 at 2. 
address. ${ }^{21}$ In qualitative research, the purpose and research questions set out the central phenomenon, concept, or process that the study will explore. However, qualitative research is an emerging process, so the purpose and research questions may change to reflect the researcher's evolving understanding as data is gathered. ${ }^{22}$

The purpose of the Best Law Teachers study is to "create the first systematic, rigorous study of excellent law teaching." 23 The study has three specific goals: "(1) identify outstanding law teachers in the United States, (2) synthesize the principles by which they teach, and (3) document those principles in a way that is useful to others."24

A literature review is a summary of the journal articles and books describing the existing information relevant to the research problem. A literature review documents the need for the study, such as filling a gap in the existing literature. ${ }^{25}$ In qualitative research, a literature review typically plays a minor role. In addition to justifying the importance of the study, a literature review can help the researcher identify the purpose of the study, the research questions, and the people who should be studied. In some qualitative research, the literature review can provide theoretical underpinnings for the study. In a grounded theory study, however, researchers need to be careful to allow the data to develop the theory, rather than having existing theories shape the researcher's view of the data. ${ }^{26}$

In the Best Law Teachers study, the authors' literature review played two roles. First, it revealed that the legal education literature contained no rigorous qualitative research of outstanding law teachers. Second, the authors' review of Ken Bain's What the Best College Teachers Do helped them design the study of law teachers. ${ }^{27}$

After designing a qualitative research study and before collecting data, educational researchers must ensure that the study complies with applicable ethical standards. In both Canada and the US, research involving human subjects is governed by federal regulations. ${ }^{28}$ In general, those regulations require higher education institutions to create ethics review boards to review faculty members' research proposals. Prerequisites for approval of the research include that risks to subjects are minimized, risks are reasonable in light of the anticipated benefits of the research, subjects give informed consent for participation in the study, and subjects' privacy and confidentiality is protected. ${ }^{29}$ The authors of the Best Law

Creswell, supra note 17 at 60 .

Ibid at 130-31.

Best Law Teachers, supra note 15 at 2.

Ibid at 4.

Creswell, supra note 17 at 80.

Johnson \& Christensen, supra note 1 at 65-66. A literature review plays a significant role in quantitative research. See Cresswell, supra note 17 at 80; Johnson \& Christensen, supra note 1 at 64 .

Ken Bain, What the Best College Teachers Do (Cambridge, Mass: Harvard University Press, 2004); Best

Law Teachers, supra note 15 at 2.

Canadian Institutes of Health Research, Natural Sciences and Engineering Research Council of Canada, and Social Sciences and Humanities Research Council of Canada, Tri-Council Policy Statement: Ethical Conduct for Research Involving Humans (December 2010), online: The Interagency Advisory Panel on Research Ethics < http://www.pre.ethics.gc.ca/pdf/eng/tcps2/TCPS_2_FINAL_Web.pdf >; Protection of Human Subjects, 34 CFR \& 97 (2013).

29 The regulations address many other aspects of human subject research and contain a number of exemptions. A detailed analysis of the regulations is beyond the scope of this article. Legal educators embarking on qualitative research should carefully review the regulations. 
Teachers study obtained approval for the study, including the informed consent forms, from Washburn University’s Human Subjects Committee. ${ }^{30}$

\section{SAMPLING}

Qualitative researchers must first decide whom to study. The goal is to identify individuals with a wealth of information related to the purpose of the study. The researchers articulate a set of criteria or attributes that subjects must possess and then seek to construct an appropriate sample of people to study. This sampling strategy is called "criterion-based selection” or "purposeful sampling."

In the Best Law Teachers study, sampling was a two stage process that lasted two years. In the first stage, the researchers solicited nominations of outstanding law teachers, "who consistently produce extraordinary learning, who change their students' lives and whose instruction stays with students long after they graduate from law school." 32 The goal of the first phase was to generate many nominations from many sources. The researchers sought nominations from law students, alumni, professors, and deans. Solicitation took place via a

Best Law Teachers, supra note 15 at 11 . The Human Subject Committee approved consent forms for subjects of the study and for students and alumni of the subjects. The consent form for subjects provided, in part:

\section{Informed Consent for Subjects of the Best Law Teachers Study}

Project Goals. The goals of this project are to identify the best law teachers in America, to synthesize the principles by which they teach as an ethic to which we (and our colleagues in legal education) can aspire, and then to share these principles and stories of these wonderful teachers by documenting them in a book.

Project Timeline. We hope to complete our research over the next two and a half years, producing What the Best Law Teachers Do (Harvard University Press) by January 2011.

Project Procedures. The project consists of four phases: (1) an initial phase during which we developed a call for nominations and solicited and received nominations (We are still taking such nominations.); (2) an investigation second phase during which we decide which nominees warrant further investigation, gather additional evidence and decide which nominees should be subjects of the study; (3) a qualitative study phase during which we visit each subject's law school, attend class sessions, interview students, alumni, peers and the nominees, and (4) an evaluation, reflection and writing phase during which we synthesize the data and write the book.

Foreseeable Risks from Participating in this Study as a Subject. At this time, we are unaware of any risks to you from participating in this study. We will be audio-taping our interview(s) with you.

Confidentiality. We are unable to assure you that your involvement in this study will remain confidential, but we will withhold names from the book and from the website upon request.

Principle Investigators/ Contact for More Information. [Omited]

Participation in This Study is Voluntary. Your participation in this project is voluntary and may be withdrawn or terminated by either the project investigator or you at any time

I, (print full name), hereby consent to participation in the Best Law Teachers Study. I have reviewed all of the information reflected on this page and voluntarily agree to be included in the study. I am aware that my conversation(s) with the principle investigators will be audio-taped.

Copies of the informed consent forms for students, alumni, and subjects are on file with the author. Johnson \& Christensen, supra note 1 at 235-36. In contrast, quantitative researchers often seek a random sample, in which each member of a population has an equal chance of being selected as a subject of the study (ibid at 219). 
website created for the study and numerous listservs related to legal education. ${ }^{33}$ Ultimately, more than 250 legal educators were nominated. ${ }^{34}$

The second stage was to select a sample of the nominees to include in the study. The researchers asked nominees to submit a statement of their teaching philosophy, two years of student evaluations of their courses, and evidence that they produced extraordinary learning in students. Although the researchers encouraged nominees to think broadly about the types of evidence to submit, they provided a list to help guide nominees:

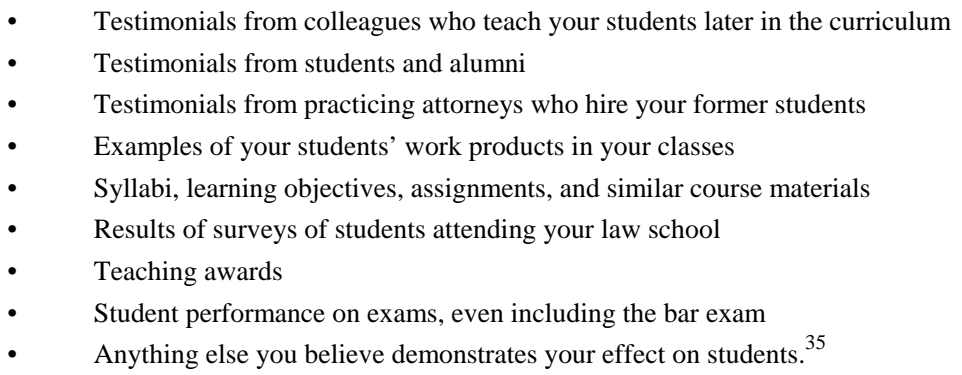

One hundred and ten nominees submitted materials in support of their nomination. One of the researchers carefully reviewed each nominee’s file. Many nominees presented very impressive evidence; those files were reviewed by at least two of the researchers. ${ }^{36}$

The researchers chose 29 law teachers to be subjects in the study, 26 of whom decided to participate. ${ }^{37}$ The subjects are broadly representative of legal educators in the US. ${ }^{38}$ Fifteen of the subjects are women; 11 are men. Five of the subjects self-identify as racial minorities. Collectively, the subjects have 530 years of law teaching experience; 16 have taught for more than 20 years. The subjects teach at law schools from every region of the US, distributed

Ibid at 5 (the listserves included 'the lawprof listserv, the associate deans' listserv, the deans' listserv, the clinic listserv, the legal writing listserv, the teaching methods listserv, and the academic support listserv.” The nomination form asked for the nominee's name, institutional affiliation, courses, teaching awards, and the nominator's basis for believing that the nominee produces extraordinary learning in students).

34 Ibid at 6. Most of the nominees are listed and their teaching is briefly described on the Best Law Teachers website ("What the Best Law Teachers Do Nominees," online: Institute for Law Teaching and Learning <http://lawteaching.org/publications/books/bestlawteachers/nominees/>).

Best Law Teachers, ibid at 8.

Ibid at 8-9.

Ibid at 10, 12-13. The subjects were Patti Alleva, University of North Dakota School of Law; Rory Bahadur, Washburn University School of Law; Cary Bricker, University of the Pacific, McGeorge School of Law; Roberto Corrada, University of Denver, Sturm College of Law; Bridget Crawford, Pace University School of Law; Meredith Duncan, University of Houston Law Center; Beth Enos, retired, Lewis \& Clark Law School; Paula Franzese, Seton Hall University School of Law; Steve Friedland, Elon University School of Law; Heather Gerken, Yale Law School; Ingrid Hillinger, Boston College Law School; Steven Homer, University of New Mexico School of Law; Don Hornstein, University of North Carolina School of Law; Nancy Knauer, Temple University, James E Beasley School of Law; Larry Krieger, Florida State University College of Law; Susan Kuo, University of South Carolina School of Law; Andy Leipold, University of Illinois College of Law; Nancy Levit, UMKC School of Law; Paula Lustbader, Seattle University School of Law; Nelson Miller, Thomas M Cooley Law School; Hiroshi Motomura, UCLA School of Law; Julie Nice, University of San Francisco School of Law; Philip Prygoski, Thomas M Cooley Law School; Ruthann Robson, CUNY School of Law; Tina Stark, Fordham University School of Law (formerly of Boston University School of Law); Andy Taslitz, deceased, American University Washington College of Law (formerly of Howard University School of Law). Ibid at 13-15. 
throughout the U.S. News and World Report rankings. ${ }^{39}$ The subjects' primary teaching duties include doctrinal courses (20 subjects), legal writing (three subjects), clinic or externship (two subjects), and academic support (one subject).

\section{DAta Collection}

Four types of data collection methods are common in qualitative research: interviews, focus groups, observation, and documents. Researchers in the Best Law Teachers study used each of these methods.

\section{A. INTERVIEWS}

Qualitative, one-on-one interviews are designed to gather in-depth information about the interviewee's thoughts, knowledge, reasoning, feelings, and motivations about a topic. The interview consists primarily of open-ended questions and prompts to gain further clarity or depth. Three types of interview structures are common in qualitative research. ${ }^{40}$ First, an informal conversational interview is loosely structured. The interviewer does not follow a protocol; instead the interviewer raises topics and follows all leads that arise from the discussion. Second, in the interview guide approach, the interviewer prepares a list of topics and questions in advance of the interview. During the interview, the interviewer may not ask the question in any particular order and may change the wording of the questions to fit the flow of the interview. Third, in a standardized open-ended interview, the interviewer prepares a complete set of questions and reads the questions in the same order to each interviewee. Interviews can take place in person, over the telephone, or via email. Face-toface or telephone interviews should be recorded, with the permission of the interviewee. ${ }^{41}$

In the Best Law Teachers study, researchers conducted face-to-face, one-on-one interviews with each of the 26 subjects. The researchers followed a guided interview approach, based on an interview protocol that included 25 questions addressing the subjects' views and practices concerning student learning, teaching methods, assessment, and relationships with students. During the interviews, the researchers asked follow-up questions to explore the topics in more detail. Each interview lasted between 90 minutes and three hours. With the permission of the subjects, most of the interviews were recorded; when recording failed, the researchers took detailed notes. ${ }^{42}$

\section{B. OBSERVATIONS}

Observation in qualitative research is the process of gathering first-hand information by observing people in the field, such as observing students in a classroom. The researcher can be in the role of participant observer, in which the researcher actually participates in the activities being observed, recording information during or after the activity. In the role of non-participant observer, the researcher watches and records the phenomenon being studied

“Best Law Schools,” online: US News \& World Report <http://grad-schools.usnews.rankingsand reviews.com/best-graduate-schools/top-law-schools/law-rankings?int=992008>.

Johnson \& Christensen, supra note 1 at 202-204.

Creswell, supra note 17 at 218-21.

Best Law Teachers, supra note 15 at 10-11. The interview protocol is reproduced at 327-28. 
without directly participating in the activity. ${ }^{43}$ In either role, the researcher produces two types of field notes. Descriptive field notes detail the phenomena observed - the activities, interactions, and happenings. Reflective field notes record the researcher's thoughts, insights, and themes that emerge from the observation. ${ }^{44}$

In the Best Law Teachers study, researchers observed each of the subjects teach one or more classes. Most of the observations took place with a researcher in the role of nonparticipant observer in the classroom, though for a few observations a researcher viewed video of a class. Researchers produced detailed field notes, including a running record of what was happening in the classroom, noting how often students were responding to questions, offering comments, or asking questions; gauging the level of student engagement; tracking the types of questions the subjects asked; and recording the subjects' teaching behaviours and techniques. Researchers noted the types of interactions between the subjects and their students in and out of the classroom. ${ }^{45}$

\section{Focus Groups}

A focus group is a small group interview conducted by a moderator. Focus groups allow researchers to gather detailed information about the participants' views of a phenomenon. Focus groups generally are more efficient than individual interviews and are especially helpful when the interaction among the group members leads to more information. Group

43 Creswell, supra note 17 at 213-15. Johnson and Christensen describe four categories of observational roles for researchers: complete participant (becoming a member of a group without informing those observed that they are in a research study), participant-as-observer (comparable to Creswell's participant observer category), observer-as-participant (comparable to Creswell's non-participant observer category), and complete observer (an outside observer who does not inform others that they are being observed as part of a research study) (Johnson \& Christensen, supra note 1 at 209).

$44 \quad$ Creswell, ibid at 217.

45 Best Law Teachers, supra note 15 at 10. Below is an excerpt of a researcher's classroom observations of one of the Best Law Teachers subjects and a researcher's post-class observation comments of another subject's class:
Time - What's Happening $(\mathrm{T}=$ Teacher $)$
11:00 Handouts delivered by $\mathrm{T}$ to each student when possible, greeting students
11:01 Welcome back. T Briefly reviews two recent news articles regarding sexuality
11:02 T Briefly review articles
11:03 T How many of you have read Catholic Charities?
11:04 T Con Law overview (Equality v. Liberty framework on board) to set context for the two cases; building Con Law background with review of cases
11:14 T - "Look at the framework — what do you make of that?" Student response. T- "Bingo, thank you."
11:15 T comments - similarities between race cases and cases for today
11:18 T creates groups and gives each group a section of an opinion to distill the best arguments in five minutes
11:20 Small group discussion (students read then discuss)
11:26 T one minute warning; each group should choose spokesperson
11:27 T briefly reviews statute and facts
11:30 Group 1 articulates and evaluates argument - T captures on board, T comments
11:34 Group 2 articulates and evaluates argument - T captures on board, T comments tying to race cases; T follow-up Qs; T "I'm asking you to think beyond the text, which you can do"; S response; T "That's a great argument”; T characterizes argument

\section{Post-Class Comments}

Engagement of all students very strong first hour

Engagement of all students strong second hour

Collaboration among students and teacher to provide feedback and make suggestions impressive

Humor from students and teacher

Students thank $\mathrm{T}$ at end of class and ask additional questions after class.

Copies of classroom observations and comments are on file with the Best Law Teachers co-authors. 
size is typically between four and 12. The moderator uses an interview protocol, consisting of a set of open ended questions. The primary role of the moderator is to facilitate the discussion - keeping the group on task, encouraging each group member to engage in the discussion, and probing for detailed responses. To preserve data from a focus group, the session is recorded and transcribed. ${ }^{46}$

In the Best Law Teachers study, researchers conducted two focus group interviews for most of the 26 subjects. One group consisted of law students who had taken one or more courses from the subject. The other group was alumni who had taken courses from the subject. For a few of the subjects, alumni were unable to attend a focus group session so the researchers interviewed them via telephone or email. The focus groups were each conducted by one of the researchers, who followed a six-question protocol. Most sessions were audiorecorded, with the permission of the participants. If recording was unavailable, the researcher took detailed notes during the session. The focus group sessions each lasted about an hour. ${ }^{47}$

\section{DoCUMENTS}

Documents are public and private records containing information about a phenomenon or research participants. Public documents include newspapers, journal articles, websites, meeting minutes, official memos, etc. Private documents include personal journals, letters, email messages, notes, etc. ${ }^{48}$

Researchers in the Best Law Teachers study collected thousands of pages of documents, which fell into four categories. First, each subject submitted a teaching philosophy statement, one to ten pages long. Second, each subject supplied two years of student evaluations of their courses, both numerical and narrative. Third, many subjects provided testimonial letters from deans, colleagues, students, and alumni. Fourth, most subjects submitted documents related to their courses, such as syllabi, assignments, and students' work product. ${ }^{49}$

\section{Data Analysis}

Data analysis in qualitative research is inductive, moving from the specific items of data to general themes. The data analysis process in qualitative research does not follow a fixed sequence. Instead, data analysis can take place simultaneously with data collection, as the researchers look for patterns and ideas in the data while continuing to collect data. Qualitative researchers analyze data by reading through it several times, organizing and categorizing the data each time. Although there is no single, uniform approach to data

Creswell, supra note 17 at 218-19; Johnson \& Christensen, supra note 1 at 204-205.

Best Law Teachers, supra note 15 at 10-11. The focus group protocol included the following questions (ibid at 329):

1. What does (did) the teacher do that fosters your learning?

2. How would you characterize the nature of your learning in the class(es)?

3. What changes in the way this teacher conducts (conducted) the class(es) would better foster your learning?

4. How is this teacher different from other teachers you have (have had)?

5. What things (if any) that you learned from this teacher have stayed with you? What did this teacher do that caused those things to stay with you? 
analysis in qualitative research, four elements are common: (1) prepare the data for analysis; (2) explore and code the data; (3) identify themes in the data; and (4) validate the accuracy of the findings. ${ }^{50}$

To prepare qualitative data for analysis, it must be organized into file folders or computer files. Recordings of interviews and notes of field observations should be transcribed. ${ }^{51}$ In the Best Law Teachers study, the researchers organized the data on a TWEN page, with one section for each of the 26 teachers. ${ }^{52}$ The section for each teacher included Word files containing transcripts of the researcher's interview with the teacher, transcripts of focus group interviews with students and alumni, notes of classroom observations, and the subject's teaching philosophy. The TWEN page contained over 1000 pages of data. In addition, two years of student evaluations for each teacher, totaling approximately 6,000 pages, were organized in file folders.

After organizing and preparing the data for analysis, qualitative researchers read through the data one or more times to get a general sense of the data. Then researchers code the data by segmenting and labeling text into descriptions and broad themes. To code the data, researchers assign a word or phrase to each sentence or paragraph that describes the meaning of each segment of data. Ultimately, the researchers will generate a list of codes relevant to the phenomenon being studied. ${ }^{53}$ In the Best Law Teachers study, each of the three researchers read through the data on the TWEN site, then each coded a third of the data. Through this process, the researchers developed a list of 95 codes. For example, codes included "passion,” "knowledgeable,” “organized,” “work ethic,” “active learning,” "respectful," "formative feedback," and "inspiring." ${ }^{4}$ The researchers trained research assistants to apply the codes to the narrative student evaluations for each subject.

After coding the data, qualitative researchers analyze the data to respond to the research questions. Researchers aim to develop deep understanding of the central phenomenon through detailed description and thematic development. Researchers aggregate codes into themes and sub-themes that emerge from the data. Detailed description of people and events

Creswell, supra note 17 at 237-38.

Ibid at 238-39.

The TWEN page was set up as a course, "What the Best Law Teachers Do," online: The West Educational Network < http://lawschool.westlaw.com/manage/homepage.aspx?courseid=122442>. The TWEN page is accessible to the co-authors of Best Law Teachers and their research students.

Creswell, supra note 17 at 238-39.

The entire list of codes was Passion (subject, student learning, student careers, practice, scholarship), Positive Affect, Energetic, Organized (presenting in class, handouts, assignments, thinking about teaching), Knowledgeable (material, category, theory, practice, skills), Creative (materials, examples and hypos, outside research, take risks/willing to be out of control), Student-Focused (use names, know lives, aware of student experience, excited by student insights and questions), Great Listening Skills, Focused on Student Learning, High Expectations (challenging, believe students will succeed, clear), Work Ethic (dedicated, scholarship), Superb Class Preparation (goal centered, materials, conscious re maximizing classroom time, tons of planning), In Classroom (flexibility, goal-centered, active learning, clear explainers, high student participation, call on students, ensure, effective use of chosen techniques, welcome diverse perspectives, facilitates student cooperation), Thoughtful and Intentional (name stuff, reasons for everything they do), Relationship With Students (assume the best, thoughtful, availability, treat as colleagues, communicate caring, mentor/advisor, teacher, coach, help students connect to others, show up), Respectful, Authentic, Inspiring, Dealing With Critical Incidents, Transformative Effect On Students (made me learn, approach to lives and work, career paths), Supportive (caring, empathetic, encouraging, e-mails), Humble (ego/no ego), Formative Feedback, Role Model/Mentor, Reflective and Interested in Continuous Improvement (feedback from students). The list of codes is on file with the Best Law Teachers co-authors. 
help illustrate the themes. ${ }^{55}$ In the Best Law Teachers study, the researchers developed seven themes related to the focus of the study to identify and document the characteristics and practices of law teachers who produce extraordinary leaning in their students: (1) personal qualities of extraordinary teachers; (2) relationships with students; (3) expectations for students; (4) preparation to teach; (5) teaching students in and out of the classroom; (6) feedback and assessment; and (7) lasting learning for students. ${ }^{56}$ Each theme contained numerous sub-themes and detailed descriptions of people and events.

Throughout the data analysis process, researchers can take steps to maximize the validity or trustworthiness of the study. Researchers face four main challenges when performing qualitative data analysis. First, researcher bias is a threat to validity. Researcher bias occurs when researchers find what they want to find by selectively recording and coding data to support the researchers' pre-existing ideas. Qualitative researchers must engage in critical self-reflection to recognize and control their biases, allowing the data to drive the results. A second challenge for qualitative researchers is descriptive validity — whether the researchers accurately describe the people, events, and behaviours that make up the phenomenon studied. One way to foster descriptive validity is through investigator triangulation, in which multiple investigators observe events and cross-check their observations to ensure that they agree about critical aspects of the phenomenon. A third concern for qualitative researchers is internal validity - whether the researchers are justified in identifying cause and effect relationships. One way to foster internal validity is through methods triangulation, in which researchers base their conclusions on the results of multiple methods of data collection, such as interviews, surveys, focus groups, and observations. Another method to enhance internal validity is data triangulation, in which researchers analyze data gathered from multiple sources, such as interviews of multiple subjects. Finally, external validity concerns whether the findings can be generalized to other people and settings. Qualitative researchers may use replication logic to establish external validity. Replication logic holds that the more times a research finding is shown to be true with different people in different places, the more confidence one can have in applying the finding to others. ${ }^{57}$

In the Best Law Teachers study, a significant validity concern was whether the researchers accurately identified the characteristics and practices common to law teachers who produce extraordinary learning in students. The researchers addressed this concern in several ways. First, the researchers based their conclusions on multiple types of data, including interviews of outstanding teachers, focus groups with students, focus groups with alumni, class observations, and student evaluations. Second, the findings were based on data gathered from 26 law teachers and their students from every region of the US representing all types of law schools. Third, the three researchers reached consensus on the themes and sub-themes that emerged from the data. ${ }^{58}$ 


\section{RESEARCH REPORT}

The structure of a qualitative research report varies considerably depending on the nature of the study. For example, some qualitative studies adopt all or most of the standard format for quantitative research: (1) title page, including the title of the study and the authors' names and institutional affiliations; (2) abstract, a concise summary of the research report; (3) introduction, including statements of the research problem, purpose, and questions; (4) literature review, summarizing themes from the existing research on the subject of the study; (5) methods, describing the sampling, participants, instruments to gather data, and the types of data collection; (6) results, detailing the data collected and the analysis of the data; (7) discussion, interpreting and evaluating the results, identifying limitations of the study, and articulating implications for future research; (8) references with citations to existing literature; and (9) appendices, such as interview protocols. ${ }^{59}$ Other qualitative research reports adopt alternative approaches. For example, a descriptive approach incorporates detailed description of people and events, such as "a day in the life" of a research subject. Another alternative is a thematic approach with an extensive discussion of the themes emerging from the data supported by numerous quotes and rich detail. ${ }^{60}$

The book, What the Best Law Teachers Do, is the research report for that study. ${ }^{61}$ The book contains many of the components of a standard quantitative research report, including the introduction, methods, results, discussion, references, and appendices. However, the primary structure of the book is thematic, with chapters devoted to the major characteristics, practices, and results obtained by outstanding law teachers. Each of those chapters contains extensive quotations from the 26 outstanding law teachers, their current students, and alumni, providing detailed descriptions in their own words. Below is a summary of those themes

\section{Chapter 3: What Personal Qualities Do the Best Law Teachers Possess?}

These teachers are deeply thoughtful about every aspect of their role as educators, from big questions of educational philosophy to small details of pedagogy. ${ }^{62}$ They are passionate, positive, energetic, creative, empathetic, and dedicated. Exceptional law teachers demonstrate expertise in their subjects and strive for continuous improvement in their performance. They are humble. One subject summarizes the qualities of outstanding teachers: "I strive to be the teacher I wanted to have and that I want to have. I want a teacher who is respectful, professional, punctual, fair, funny, knowledgeable, humble, accessible, encouraging, forgiving (but not lax), hard-working, and rigorous.”,63

reswell, supra note 17 (chart summarizing the typical structure of a quantitative research study at 273); Johnson \& Christensen, supra note 1 (describing each element of a typical quantitative research report at 557-62 and applying the elements to qualitative research at 574-77).

Creswell, supra note 17 (also describing a scientific approach, storytelling approach, theoretical approach, and other creative approaches to qualitative research reports at 274-76).

Best Law Teachers, supra note 15.

Ibid at 37-75.

Ibid at 75 . 


\section{Chapter 4: How Do the Best Law Teachers Relate to Their Students?}

The relationships between these teachers and their students are founded on mutual respect. Exceptional teachers know their students' names, backgrounds, and aspirations. They demonstrate concern for every student in the classroom, outside of law school, and after graduation. They make time for their students. Outstanding teachers become role models and mentors for their students. ${ }^{64}$ One teacher describes the power of caring and respect: "Nothing can substitute for caring for and respecting one's students. What matters most to students are the invisible things - not the showy teaching style, but a willingness to learn every one of their names..., give them feedback, take them out to lunch, help them think through career choices." 65

\section{Chapter 5: What Do the Best Law Teachers Expect from Their Students?}

Students respond positively to their teachers' high, clear, achievable expectations. Exceptional teachers have confidence that every student can succeed. Through their own work ethic and professionalism, these teachers inspire their students to strive for excellence. ${ }^{66}$ Many students note the motivational aspects of their teachers' high expectations. Two students describe the expectations of one subject: "He expects the best from everybody. And I think it's sort of reciprocal because I think he give us the best too. It's very clear in his class that you are expected to work very hard and you're expected to turn in a good product," and, "It's quite remarkable that he does that and pushes the way he does without it becoming threatening., 67

\section{Chapter 6: How Do the Best Law Teachers Prepare to Teach?}

These teachers prepare extensively for class. Although they each prepare in unique ways, the following teacher's description is typical of the depth of preparation:

\footnotetext{
I prepare quite extensively for class, even if it is material I have taught many times before. ... I read every assignment several times:
}

I first read as a student. ... I look for new concepts or aspects of the readings that might be difficult, unfamiliar, or dissonant. ...

I then read as a lawyer. ... I look for any lawyering aspects of the material, including procedural matters.

Finally, I read as a law professor. I think about how the material fits into the overall learning goals for the semester and how the material could be tested. I evaluate it for how it relates to the previous classes and how it relates to future classes. I think carefully how the material should be taught to this class at this time. ${ }^{68}$ 
Chapter 7: How Do the Best Law Teachers Engage Students in and out of the Classroom?

The teaching styles of these excellent law teachers vary tremendously. Yet they share several core teaching behaviours. First, they deliberately structure their classes to help students achieve learning goals. Second, they demonstrate that they care about student learning by listening closely, showing excitement for student insights, and making learning fun. Third, they make their classes relevant by connecting the material to everyday life and law practice. Fourth, they excel at their chosen teaching methods, actively engaging students. Many end their courses with an inspiring talk or activity. ${ }^{69}$ "I share with them how special it is for me to watch them grow as lawyers and what that experience is like for me.... I always tell them 'Never tell yourself you're stupid because you are new at something. Never tell yourself that you're stupid because you're nervous about something.",70

\section{Chapter 8: How Do the Best Law Teachers Provide Feedback and Assess Students?}

Many of these teachers give students multiple and varied opportunities for practice and feedback, even when they teach large classes. They use midterm exams, quizzes, practice exams, writing assignments, problems, hypotheticals, and simulations. Students characterize the teachers' exams as difficult but fair. ${ }^{71}$ One teacher commented, "To me the exam is itself a capstone learning experience ... a vehicle for them to really to demonstrate their knowledge and skills."72

\section{Chapter 9: What Lasting Lessons Do Students Take Away?}

Students identify lasting learning from their extraordinary law teachers, including deep understanding of law and theory, critical thinking, professional judgment, and writing and advocacy skills. Many students model themselves on the characteristics and values of these teachers, including passion, humility, excellence, respect, ethics, and professionalism. One alum commented, "I now get to pay my mortgage by doing something morally rewarding every single day. I can honestly say I've never had to do anything as a lawyer that ever left me morally conflicted. This would not have been possible without [the teacher's] guidance."73

\section{CONCLUSION}

One purpose of this article is to encourage legal educators to engage in high quality qualitative research on legal education. To further that goal, the article provides a framework for qualitative educational research, illustrated by the Best Law Teachers study. 
The educational research literature contains criteria and checklists for evaluating qualitative research. ${ }^{74}$ The following standards by Creswell are clear and concise:

- It employs rigorous data collection, which involves multiple forms of data, extensive data and long periods in the field collecting data.

- It is consistent with the philosophical assumptions and characteristics of a qualitative approach to research. These include an evolving design, the presentation of multiple perspectives, the researcher as an instrument of data collection, and the focus on participants' views.

- It employs a tradition of inquiry such as case study, ethnography, grounded theory, or narrative inquiry as a procedural guide to the study.

- It starts with a single focus on a central phenomenon rather than a comparison or relationship (as in quantitative research).

- It is written persuasively so that the reader experiences being there.

- Analysis consists of multiple levels of analysis to portray the complexity of the central phenomenon.

- $\quad$ The narrative engages the reader because of unexpected ideas and believable and realistic information.

- It includes strategies to confirm the accuracy of the study. ${ }^{75}$

Legal educators should strive to meet these standards in order to produce high quality qualitative research to help guide the future of legal education. Many legal education topics are ripe for qualitative research. Here are seven potential topics: (1) student learning of doctrine, skills, and professionalism in a clinical course; (2) teacher and student experiences in various course formats - face-to-face, online, blended; (3) mentor relationships — faculty to faculty, faculty to student, student to student; (4) developing a rigorous externship program; (5) student development of professionalism through three years of law school; (6) faculty development programs — scholarship and teaching; and (7) graduates' successes and struggles in the first two years of practice. The results of that research could help inform important decisions for law teachers and law schools facing the challenges of the 21st century. at 285 and checklist for evaluating qualitative research at 287); Johnson \& Christensen, supra note 1 (checklist for evaluating qualitative research at 80). 